\title{
Empowering the Principal of Boarding House-Based Junior High School in East Java Province Indonesia
}

\author{
Desi Eri Kusumaningrum \\ Department of Educational Administration \\ State University of Malang, Indonesia \\ desi.eri.fip@um.ac.id
}

\author{
Raden Bambang Sumarsono \\ Department of Educational Administration \\ State University of Malang, Indonesia \\ raden.bambang.fip@um.ac.id
}

\author{
Imam Gunawan \\ Department of Educational Administration \\ State University of Malang, Indonesia \\ imam.gunawan.fip@um.ac.id
}

\begin{abstract}
This research aimed to know the level of empowerment of the principal of boarding house-based Junior High School in East Java, Indonesia. The research method used in this research was a descriptive quantitative method. This research was conducted in boarding house-based Junior High School in East Java Province, Indonesia. The samples were taken using a stratified random sampling technique. The research subjects were principals. The research instrument used was the questionnaire measuring the level of the empowerment of the principal with 61 items of the question. The data analysis employed was descriptive statistic by calculating the mean, standard deviation, and descriptive analysis of the category of each from 61items scores. The level of the empowerment of the principal was determined based on the high categorized-percentage from the descriptive analysis result of the category of each item namely it is high if it is $\geq 50 \%$, and it is low if it is $<50 \%$. Based on the descriptive analysis, the mean was 4.31 and the standard deviation was 0.46 . The descriptive analysis results of every item category were from 61 items, there were 29 items (47.54\%) categorized high while the rests were 32 items (52.46\%) in the low category. Besides, the results showed that the level of empowerment of the principal was lowly categorized (47.54\%).
\end{abstract}

Keywords: empowerment, principal, Junior High School, boarding house-based school

\section{INTRODUCTION}

A principal is a key man in improving the quality of school education. The principal as a leader must be able to carry out his/her duty as a leader of education by empowering all school resources. Therefore, before empowering the school resources, the principal should be able to empower him/herself for the school enhancement. The principal as the leader of education has a crucial role in empowering all school resources. Empowerment will moderate the relationship between empowering leadership and creativity (Özarall, 2015). Erkutlu and Chafra (2015), based on their research, concluded that empowering leadership is positively and significantly correlated with employees' organizational job embeddedness. By empowerment we mean increasing both the capacity of individuals or groups to make purposeful choices and their capacity to transform these choices into desired actions and outcomes (Petesch, et al., 2005).

Pradhani and Imron (2016), based on their research results, inferred that the principal's role as an educator, manager, administrator, and supervisor is to know the principal's success in teacher professionalism developing the sustainable profession. The problem related to the quality of education can be solved by empowering human as subject and object of development. Human in a certain country can support the success of development or burden it. The human can support the success of development when the human's potential can be optimally developed and empowered. Meanwhile, the human's potential that cannot be empowered and developed will be the burden of development. The essence of the human's empowerment, according to Usman (2009) is how to prepare the productive man in development giving benefit for themselves, their family, social environment, religion, nation, and country.

Human resources empowerment in the school needs the principal focusing his/her attention to all components available in the school. Arikunto, et al., (2006) concluded the principal's performance can be seen from six components of school supervisory object namely students, teachers, curriculum, facilities and infrastructure, fund, school management, and school culture. The implementation of the school's role as a leader could improve the teacher's performance (Anggraeni, et al., 2016). The principal as the leader of education should be able to empower all school resources. The principal must be able to apply the empowerment model to reach the school goal. The principal must know the potential, skills, competency, and passion of each human resource in the school to assign the duty and responsibility of a job. This research aimed to know the level of empowerment of principal of boarding house-based Junior high School in East Java, Indonesia.

\section{METHODS}

This research used a descriptive quantitative method. The research was conducted in boarding house-based Junior High School in East Java Province, Indonesia, namely: (1) SMP Assa'adah Gresik representing the northern East Java; (2) SMP Insan Terpadu Probolinggo representing the eastern East Java; (3) SMP An-Nur Bululawang Malang representing the southern East Java; and (4) SMP 
Mambaul Hisan Kediri representing the western East Java. The sampling technique was by a stratified random sampling where the researcher selects the sample member in the group not separately (Gunawan, 2016c; Gunawan, 2013; Gunawan, 2916c). The research subjects were the principals of boarding house-based Junior High School in East Java Province, Indonesia, measuring the level of empowerment of the principal of boarding house-based Junior High School, East Java Province, Indonesia, with 61 items of the question. The data analysis used a descriptive analysis of each item category from the score of 61 items.

The item category was used to describe every statement of the item through the mean of each item score determined by dividing the total scores of items with the number of respondents. After that, the mean of each item score was compared to the mean all items scores using the requirement namely (1) if the mean of each item score is $>$ the mean of all items scores, it means that the item is categorized high $(\mathrm{H})$, and (2) if the mean of the score of item $\leq$ the mean of the scores of all items, it means that the item is categorized as low (L). Each item statement categorized as high is the description of variable indicator that should be maintained while the item categorized as low is the description of variable indicator that should be improved (Arikunto, 2014). The level of empowerment of the principals of boarding house-based Junior High School in East Java, Indonesia was determined based on the high category percentage from the results of descriptive analysis of every item category namely it is high if it is $\geq 50 \%$ and it is low if it is $<50 \%$.

\section{RESULTS}

The data of empowerment of the principals of boarding house-based Junior High School in East java, Indonesia are presented in Table 1. Based on Table 1, the mean was 4.31 and the standard deviation was 0.46 . The results of descriptive analysis of each item category by comparing the mean of all items scores and the mean of each item score are presented in Table 1 .

Based on descriptive analysis of the category of each item presented in Table 1, we can know that from 61 items there are 29 items $(47.54 \%)$ were categorized high since the mean of the score of each item $>$ the mean of the scores of all items. The high categorized items were the number of $5,10,15,23,24,25,27,30$, $32,33,34,41,42,43,44,45,46,47,48,50,52,53,54$, $55,56,58,59,60$, and 61 . This means that the description of the indicator of principal empowerment in the item numbers should be maintained. Meanwhile, the rests of 32 items $(52.46 \%)$ were included in the low category since the mean of each item score was $\leq$ the mean of all items scores. The items in the low category were the number of $1,2,3,4,6,7,8,9,11,12,13,14$, $16,17,18,19,20,21,22,26,28,29,31,35,36,37,38$, 39, 40, 49, 51, and 57. This case means that the description of the indicator of principal empowerment should be enhanced. Based on the percentage of the descriptive analysis results of each item, the level of the empowerment of the principals of boarding house- based Junior High School in East Java Indonesia had a low category $(47.54 \%)$.

\section{DISCUSSION}

The principal is the leader of education in the school. The principal is the key man in improving the quality of education in the school. Therefore, a principal is the main and first actor that should be empowered in the school. The principal is the parameter of the advance of the school. The leader of education in the school is the principal (Gunawan, 2016a). Empowerment is not only giving responsibility and accountability for a task but also the responsibility and authority to make decisions tied to the assignment while, again, retaining control and accountability (Stone, 2004). Empowering leaders can obtain more trust, loyalty, satisfaction and identification from their employees (Amundsen dan Martinsen, 2014; Hon, 2011). Leaders are people who often receive their power through inspiring trust, communicating a vision, focusing on the group process, demonstrating concern for subordinates and the empowering of others (Bennis dan Nanus, 1985; Kouzes dan Posner, 1987; PorterO'Grady, 1992). The principal should make a synergy with the teacher and staff to solve a certain task and get the support of funding and facility (Sudayat, 2014).

The empowerment of the principal is related to how to create a good working atmosphere, decision making, self-confidence, facility providing, and running authority as the leader of education in the school. The five factors influence the creation of the working place, psychological condition, organization commitment, and the presence of a leader. The principal is the driving force, the determinant of the school policy orientation determining the school goal that finally can realize the quality of education (Ekosiswoyo, 2007). The indicated of the types of empowering principal developing common beliefs about learning, connecting teaching and learning, highlighting successes in teaching and learning, serving the community, demonstrating a caring community, increasing outside information, facilitating change, building trust through communication, modeling inclusion and collaboration, and empowering student leaders (Bastian, 1995). The most commonly attended forms of professional development are conferences organized by the principals' association; the most valued professional development activities are those classified as learning on the job or involving interpersonal skill development (Bezzina, 1994).

Obstacles to empowering principal which were identified are time, isolation, fear of risk-taking, communication, technology, connectedness, and powerlessness and frustration (Bastian, 1995). Principals attended more professional development activities than their male, religious, and secondary counterparts respectively (Bezzina, 1994). However, if the leader does not delegate, the employee will never be empowered (Peachey, 2002). Delegation is the giving an employee the responsibility for part of your job and the authority to carry it out, while retaining control and accountability (Stone, 2004). 
Table 1

The Comparison of the Mean of All Items Scores and the Mean of Each Item Score

\begin{tabular}{|c|c|c|c|c|c|}
\hline No & Statement & $\sum$ & $\mathbf{n}$ & $\bar{X}$ & Note \\
\hline 1 & You have specific documents/information of the things done. & 16 & 61 & 4.00 & $\mathrm{~L}$ \\
\hline 2 & You have specific notes/comments about the things that can improve the performance. & 17 & 61 & 4.25 & $\mathrm{~L}$ \\
\hline 3 & You have the guidance or problem-solving based on the suggestion given by the other people. & 17 & 61 & 4.25 & $\mathrm{~L}$ \\
\hline 4 & You note the recommendation related to the job/task given by the other people. & 17 & 61 & 4.25 & $\mathrm{~L}$ \\
\hline 5 & The teachers discuss the program of training or education that will be carried out. & 18 & 61 & 4.50 & $\mathrm{H}$ \\
\hline 6 & You help the teachers and staffs when they face difficulty in doing their jobs. & 17 & 61 & 4.25 & $\mathrm{~L}$ \\
\hline 7 & Your help can be accessed by the teachers and staffs in doing the job. & 15 & 61 & 3.75 & $\mathrm{~L}$ \\
\hline 8 & $\begin{array}{l}\text { You help the teachers and staffs in obtaining the material and equipment needed to undertake } \\
\text { the job. }\end{array}$ & 15 & 61 & 3.75 & $\mathrm{~L}$ \\
\hline 9 & You give reward and acknowledgment to the teachers and staffs doing the job well. & 17 & 61 & 4.25 & $\mathrm{~L}$ \\
\hline 10 & The school condition. & 18 & 61 & 4.50 & $\mathrm{H}$ \\
\hline 11 & The working relationship of the school unit. & 17 & 61 & 4.25 & $\mathrm{~L}$ \\
\hline 12 & How do the other people in the female/male teacher's position run their job? & 14 & 61 & 3.50 & $\mathrm{~L}$ \\
\hline 13 & The values applied by the school principal. & 17 & 61 & 4.25 & $\mathrm{~L}$ \\
\hline 14 & The goal formulated by the school principal. & 17 & 61 & 4.25 & $\mathrm{~L}$ \\
\hline 15 & This year plan. & 18 & 61 & 4.50 & $\mathrm{H}$ \\
\hline 16 & How is the decision of salary made by the principal? & 16 & 61 & 4.00 & $\mathrm{~L}$ \\
\hline 17 & Does the other unit also think of your unit? & 13 & 61 & 3.25 & $\mathrm{~L}$ \\
\hline 18 & Having enough time to conduct the job. & 17 & 61 & 4.25 & $\mathrm{~L}$ \\
\hline 19 & The available time to archive the needed document. & 14 & 61 & 3.50 & $\mathrm{~L}$ \\
\hline 20 & The available time to finish the job is in accordance with the standard. & 16 & 61 & 4.00 & $\mathrm{~L}$ \\
\hline 21 & Attaining temporary assistance if necessary. & 14 & 61 & 3.50 & $\mathrm{~L}$ \\
\hline 22 & Influencing the decision of job division of Human Resources in the school. & 16 & 61 & 4.00 & $\mathrm{~L}$ \\
\hline 23 & Influencing the decision of the recruitment of Human Resources in the school. & 18 & 61 & 4.50 & $\mathrm{H}$ \\
\hline 24 & Influencing the decision of providing the facilities for the school. & 18 & 61 & 4.50 & $\mathrm{H}$ \\
\hline 25 & The job challenge. & 18 & 61 & 4.50 & $\mathrm{H}$ \\
\hline 26 & The opportunity to achieve knowledge and skills in the work. & 17 & 61 & 4.25 & $\mathrm{~L}$ \\
\hline 27 & Access to the training program to learn the new things. & 18 & 61 & 4.50 & $\mathrm{H}$ \\
\hline 28 & The opportunity to learn how the school works. & 16 & 61 & 4.00 & $\mathrm{~L}$ \\
\hline 29 & The jobs that use your all knowledge and skills. & 16 & 61 & 4.00 & $\mathrm{~L}$ \\
\hline 30 & The opportunity to be developed in the more challenging and better job and duty. & 18 & 61 & 4.50 & $\mathrm{H}$ \\
\hline 31 & The chance to assume the different role that is not related to your job now. & 16 & 61 & 4.00 & $\mathrm{~L}$ \\
\hline 32 & The job I do is important for me. & 20 & 61 & 5.00 & $\mathrm{H}$ \\
\hline 33 & The job I do is meaningful for me. & 18 & 61 & 4.50 & $\mathrm{H}$ \\
\hline 34 & The job I do is essential for me. & 18 & 61 & 4.50 & $\mathrm{H}$ \\
\hline 35 & I believe in my skills to do my job. & 15 & 61 & 3.75 & $\mathrm{~L}$ \\
\hline 36 & I believe in my skills to the activities in my work. & 17 & 61 & 4.25 & $\mathrm{~L}$ \\
\hline 37 & I have mastered the knowledge and skills needed for my job. & 15 & 61 & 3.75 & $\mathrm{~L}$ \\
\hline 38 & I have a significant autonomy in determining how I do my job. & 16 & 61 & 4.00 & $\mathrm{~L}$ \\
\hline 39 & I can decide how to do my job. & 15 & 61 & 3.75 & $\mathrm{~L}$ \\
\hline 40 & I have a big chance to freely determine how to do my job. & 15 & 61 & 3.75 & $\mathrm{~L}$ \\
\hline 41 & My effect on what happens in the school is big. & 18 & 61 & 4.50 & $\mathrm{H}$ \\
\hline 42 & I have many controls of what happens in my school. & 20 & 61 & 5.00 & $\mathrm{H}$ \\
\hline 43 & I significantly influence what happens in my school. & 20 & 61 & 5.00 & $\mathrm{H}$ \\
\hline 44 & I like to spend my carrier span in this school. & 18 & 61 & 4.50 & $\mathrm{H}$ \\
\hline 45 & Now, by living with my school, the problem is the needs as many as my wants. & 19 & 61 & 4.75 & $\mathrm{H}$ \\
\hline 46 & I think that I have to live with my school now. & 19 & 61 & 4.75 & $\mathrm{H}$ \\
\hline 47 & I really think as if the organization problems are my own problems. & 20 & 61 & 5.00 & $\mathrm{H}$ \\
\hline 48 & I am difficult to leave the school even if I want to leave it. & 19 & 61 & 4.75 & $\mathrm{H}$ \\
\hline 49 & If it is for my benefit, I do not feel that I will really leave the school. & 17 & 61 & 4.25 & $\mathrm{~L}$ \\
\hline 50 & I have a hard feeling that I belong to this school. & 19 & 61 & 4.75 & $\mathrm{H}$ \\
\hline 51 & Many things in my life will be ruined if I decided to leave my organization now. & 16 & 61 & 4.00 & $\mathrm{~L}$ \\
\hline 52 & I will feel guilty if I leave my school. & 20 & 61 & 5.00 & $\mathrm{H}$ \\
\hline 53 & I feel emotional/having heart bond with the school. & 20 & 61 & 5.00 & $\mathrm{H}$ \\
\hline 54 & I feel that I have too few choices to consider leaving the school. & 18 & 61 & 4.50 & $\mathrm{H}$ \\
\hline 55 & The school is appropriate to have my loyalty. & 20 & 61 & 5.00 & $\mathrm{H}$ \\
\hline 56 & I feel as the part of the family in the school. & 20 & 61 & 5.00 & $\mathrm{H}$ \\
\hline 57 & $\begin{array}{l}\text { If I have not positioned many things of myself in this organization, I may consider working in } \\
\text { another place. }\end{array}$ & 13 & 61 & 3.25 & $\mathrm{~L}$ \\
\hline 58 & I will not leave the school since I have the obligation for the people in it. & 19 & 61 & 4.75 & $\mathrm{H}$ \\
\hline 59 & The school gives many personal meanings for myself. & 18 & 61 & 4.50 & $\mathrm{H}$ \\
\hline 60 & $\begin{array}{l}\text { One of the negative consequences if I leave the school is there will be available alternative } \\
\text { Human Resources scarcity. }\end{array}$ & 19 & 61 & 4.75 & $\mathrm{H}$ \\
\hline \multirow[t]{2}{*}{61} & I have a debt of gratitude to the school. & 19 & 61 & 4.75 & $\mathrm{H}$ \\
\hline & 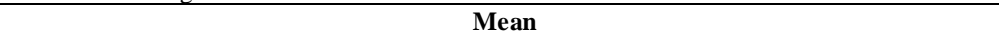 & 17.23 & - & 4.31 & - \\
\hline
\end{tabular}

By helping school administration personnel (school staff) to psychologically own changes, principals are more likely to see changes become sustained and embedded in practice (Bowers, 2011).
The empowerment of staff needs the leadership skill to treat the staff as the partner, not the subordinate (Sudayat, 2014). The empowerment of principal in building the quality of education by doing a planned 
class supervision and the empowerment of teacher by giving the chance to the teacher to join a training or seminar, and obligate the teacher to join Teacher Working Group (Fathurrahman, 2012). Empowerment is a process in which providers enable to think critically and act autonomously to ensure can make their own decisions and take control of their (Wang, et al., 2016).

Principals and teacher leaders responded to five essential questions regarding what works, what does not work, the incentives, and the costs of principal leadership behaviors under empowerment paradigms (Maxfield dan Flumerfelt, 2009). Principals' leadership empowerment behavior was a significant predictor of teachers' innovative behavior and innovative climate; innovative climate was found to partially mediate the relationship between principals' leadership empowerment behavior and teachers' innovative behavior (Sagnak, 2012). Emergent themes of principal empowerment paradigms were identified from two perspectives, that of practicing principals and that of emerging teacher leaders (Maxfield dan Flumerfelt, 2009).

\section{CONCLUSION}

Based on the descriptive analysis results, the mean was 4.31 and the standard deviation was 0.46 . From 61 items, there were 29 items $(47.54 \%)$ were categorized as high while 32 items $(52.46 \%)$ were categorized as low. Besides, the level of empowerment of the principal of boarding house-based Junior High School in East Java, Indonesia was included in the low category $(47.54 \%)$

\section{ACKNOWLEDGMENT}

We would like to thank the Directorate of Research and Social Responsibility, General Directorate of Research and Development Reinforcement, the Ministry of Research, Technology, and High Education that have funded this research in the Scheme of Applied Product Research Fiscal Year of 2017. We also say gratitude to the Institution of Research and Social Responsibility of Universitas Negeri Malang (UM) that has supported this study.

Additionally, we send the acknowledgment to the Dean of the Faculty of Educational Sciences of Universitas Negeri Malang (UM) that has supported this research. Last but not the least, we also thank SMP Assa'adah Gresik; SMP Insan Terpadu Probolinggo, SMP An-Nur Bululawang Malang, and SMP Mambaul Hisan Kediri that have been willing to be the subject of this research.

\section{REFERENCES}

[1] Amundsen, S., and Martinsen, L. 2014. Empowering Leadership: Construct Clarification, Conceptualization, and Validation of a New Scale. The Leadership Quarterly, 25, 487-511.

[2] Anggraeni, G. N., Kusmintardjo, and Nurabadi, A. 2016. Implementasi Peran Kepala Taman Kanak-kanak (TK) dalam Meningkatkan Kinerja Guru. Manajemen Pendidikan, 25(1), 10-17.
[3] Arikunto, S. 2014. Prosedur Penelitian: Suatu Pendekatan Praktik. Jakarta: Rineka Cipta.

[4] Arikunto, S., Suyanto, S., and Raharja, S. 2006. Pengembangan Kapasitas Kepengawasan Pendidikan di Wilayah Kota Yogyakarta. Jurnal Penelitian BAPPEDA Kota Yogyakarta, 1(1), 3-11.

[5] Bastian, K. H. 1995. Empowering Principal Leadership in Democratic Schools. Dissertation. Texas: Texas Tech University.

[6] Bennis, W., and Nanus, B. 1985. Leaders - The Strategies for Making Change. New York: Harper and Row Publishers.

[7] Bezzina, M. 1994. Empowering the Principal through Professional Development. Paper Presented at The Annual Conference of the Australian Teacher Education Association, Brisbane, Queensland, Australia, July 3-6.

[8] Bowers, B. 2011. Managing Change by Empowering Staff. Nursing Times, 107(33), 19-21.

[9] Ekosiswoyo, R. 2007. Kepemimpinan Kepala Sekolah yang Efektif Kunci Pencapaian Kualitas Pendidikan. Jurnal Ilmu Pendidikan, 14(2), 76-82.

[10] Erkutlu, H., and Chafra, J. 2015. Empowering Leadership and Organizational Job Embeddedness: the Moderating Roles of Task Interdependence and Organizational Politics. International Conference on Leadership, Technology, Innovation and Business Management, Procedia - Social and Behavioral Sciences, p. 3-10, Retrieved January 11, 2018, from http://www.sciencedirect.com.

[11] Fathurrahman, M. 2012. Pemberdayaan Kepala Sekolah dalam Membangun Mutu Pendidikan di Kabupaten Barito Kuala. Thesis. Yogyakarta: Universitas Negeri Yogyakarta.

[12] Gunawan, I. 2013. Statistika untuk Kependidikan Sekolah Dasar. Yogyakarta: Penerbit Ombak.

[13] Gunawan, I. 2016a. Merevitalisasi Kepemimpinan Pancasila dalam Bidang Pendidikan. Proceedings National Seminar Penguatan Manajemen Pendidikan di Era Kompetisi Global, Jurusan Administrasi Pendidikan Universitas Negeri Malang, Malang, 12 March, p. 67-84.

[14] Gunawan, I. 2016b. Metode Penelitian Kuantitatif. Retrieved June 7, 2017, from http://fip.um.ac.id/wpcontent/uploads/2015/12/2_Metpen-Kuantitatif.pdf.

[15] Gunawan, I. 2016c. Pengantar Statistika Inferensial. Jakarta: Rajawali Pers.

[16] Hon, A. H. Y. 2011. Enhancing Employee Creativity in the Chinese Context: The Mediating Role of Employee Self-Concordance. International Journal of Hospitality Management, 30, 375-384.

[17] Kouzes, J., and Posner, B. 1987. The Leadership Challenge. San Francisco: Josey-Bass.

[18] Maxfield, C. R., and Flumerfelt, S. 2009. The Empowering Principal: Leadership Behaviors Needed by Effective Principals as Identified by Emerging Leaders and Principals. International Journal of Teacher Leadership, 2(2), 39-48.

[19] Özarall, N. 2015. Linking Empowering Leader to Creativity: The Moderating Role of Psychological (Felt) Empowerment. International Conference on Leadership, Technology and Innovation Management, Procedia - Social and Behavioral Sciences, p. 447-454, Retrieved January 11, 2018, from http://www.sciencedirect.com.

[20] Peachey, G. A. 2002. The Effect of Leader Empowering Behaviours on Staff Nurses Workplace Empowerment, Psychological Empowerment, Organizational Commitment, and Absenteeism. Thesis. Hamilton, Ontario: McMaster University. 
[21] Petesch, P., Smulovitz, C., and Walton, M. 2005. Evaluating Empowerment: A Framework with Cases from Latin America. Dalam Narayan, D., (Eds)., Measuring Empowerment: Cross Disciplinary Perspectives. Washington, DC: The World Bank.

[22] Porter-O'Grady, T. 1992. Transfonnational Leadership in an Age of Chaos. Nursing Administration Quarterly, 17(1), 17-24.

[23] Pradhani, M. W., and Imron, A. 2016. Peran Kepala Sekolah dalam Pengembangan Keprofesian Berkelanjutan Guru Bersertifikat Pendidik. Manajemen Pendidikan, 25(1), 18-29.

[24] Sagnak, M. 2012. The Empowering Leadership and Teachers' Innovative Behavior: The Mediating Role of Innovation Climate. African Journal of Business Management, 6(4), 1635-1641.

[25] Stone, F. 2004. From Delegating to Empowering. New York: Kaplan Professional.

[26] Sudayat, A. T., Ulfatin, N., and Sobri, A. Y. 2014. Pemberdayaan dan Pengembangan Sumber Daya Manusia pada Sekolah Inklusi. Ilmu Pendidikan, 41(2), 109-115.

[27] Usman, H. 2009. Manajemen: Teori, Praktik, dan Riset Pendidikan. Jakarta: PT Bumi Aksara.

[28] Wang, R. H., Hsu, H. C., Lee, Y. J., Shin, S. J., Lin, K. D., and An, L. W. 2016. Patient Empowerment Interacts with Health Literacy to Associate with Subsequent Self-Management Behaviors in Patients with Type 2 Diabetes: A Prospective Study in Taiwan. Patient Education and Counseling, http://dx.doi.org/10.1016/j.pec.2016.04.001. 